\title{
Fiscal Decentralization and Nigerian Macroeconomic Performance and Economic Stability
}

\author{
Osmond N. Okonkwo ${ }^{1}$ \& Egbulonu K. Godslove ${ }^{2}$ \\ ${ }^{1}$ Department of Economics, Alvan Ikoku Federal College of Education, Owerri, Nigeria \\ ${ }^{2}$ Department of Economics, Faculty of Social Sciences, Imo State University, Owerri, Nigeria \\ Correspondence: Osmond N. Okonkwo, Department of Economics, Alvan Ikoku Federal College of Education, \\ Owerri, Nigeria. Tel: 234-805-722-0050. E-mail: osmond.okonkwo@gmail.com
}

Received: November 7, 2014

Accepted: December 4, 2014

Online Published: January 25, 2015

doi:10.5539/ijef.v7n2p113

URL: http://dx.doi.org/10.5539/ijef.v7n2p113

\begin{abstract}
This study seeks to investigate the impact of fiscal decentralization on macroeconomic performance and stability in Nigeria. It analyzes the effects of the core fiscal decentralization variables of revenue and expenditure decentralization, and fiscal dependence ratio on macroeconomic performance and stability of the Nigerian economy, where macroeconomic performance is proxied by the misery index (which is the combination of inflation and unemployment rates). The error correction mechanism was employed in estimating the model of this study. Findings of the study provided strong evidence that fiscal decentralization and fiscal dependence ratio have significant impact on macroeconomic stability in Nigeria with the expected signs of magnitude. The stability test revealed that estimated parameters of the study are stable and useful for policy decision.
\end{abstract}

Keywords: fiscal decentralization, macroeconomic performance, macroeconomic stability and Misery index

\section{Introduction}

Fiscal decentralization refers to a situation where governmental functions and revenue sources are divided among central and subnational (states and local) governments. Nigeria had evolved from unitary to fiscal decentralization during the colonial era and there seem to be continued growing agitation for deeper decentralization from different quarters in the Nigeria space. The argument is that fiscal decentralization improves macroeconomic performance and stability.

Hence Nigeria keep evolving and reshaping its fiscal Federalism through different reforms over the years in order to promote macroeconomic performance of the economy thereby providing public goods to reflect the aspirations of the people at the subnational levels. Fiscal decentralization is the dynamic interaction between different levels of government and therefore poses questions as to how the nature and condition of the fiscal relation in any Federal system affect the production and distribution of the wealth of a nation, it influences how political decisions and interests influence the location of economic activities and distribution of the cost and benefit of these activities.

While further agitations for the devolution of expenditure and revenue responsibilities to the three levels of governments in Nigeria continue, governmental functions in Nigeria are divided into two; the exclusive list and the concurrent list. The exclusive list consists of items and functions left for the Federal (Central) government alone, while the concurrent list consists of items and functions which both the central and State governments can legislate on. This is contained in the second schedule part II of the 1995 constitution. However, the inclusion of items in the exclusive and concurrent list is based on the theory of fiscal federalism. Hence the division of Governmental activities among different levels of government in Nigeria require the division of overall revenue structure, that is, different taxes being apportioned to be levied and administered by different levels of Government (Nnamocha, 2002).

Revenue decentralization in Nigeria has been the outcome of commissions set up to determine how best revenue should be shared among the tiers of governments at different times. Revenue allocation had been between the Federal Government and the state government until after the local government area (L.G.A) reform of 1976 that the L.G.As are included in the revenue allocation in Nigeria. The revenue allocation commissions are required to look into the various sources of revenue and advice on how the government revenue should be shared among the 
various levels of government and among the units in a level of government. Revenue allocation and the sharing of responsibilities among the tiers of Government can be said to have started in 1946 by Phillipsons commission of 1946, then Hicks-Phillipson commission of 1951, chicks commission of 1953, Raisman commission of 1964, Dina committee of 1969, Aboyade's Technical committee of 1977, Okigbo's commission of 1980, allocation of Revenue Act of 1981, Allocation of Revenue Amendment Decree of 1984 Danjuma commission of 1988 and the National Revenue Mobilization Allocation and Fiscal Commission (NRMAFC) established by Decree No 49 of 1989 as an independent and autonomous commission and is not subject to the direction of any other authority or person in the exercise of its powers.

The inter-governmental fiscal relations in Nigeria are skewed in favor of the Federal government which has far less to do with the daily lives of citizens while the states and local governments that are grass root based governments with far reaching effects on the people especially the majority that live in rural areas are starved of the needed funds for development. It can be inferred that fiscal federalism is at the core of most of the macroeconomic instability in Nigeria. The Federal Government is too powerful and inevitably very corrupt hence there are little or nothing to show for so much revenue allocated over time hence the continued debate and agitation for further and further fiscal decentralization in Nigeria, as a result, the revenue allocation formula has never been satisfactory to the different tiers of governments neither are they generally acceptable to the people.

Thus, the objective of this study is to analyze the empirical effects of fiscal decentralization (revenue and expenditure) on macroeconomic performance and stability in Nigeria.

\section{Review}

\subsection{Theoretical Framework}

\subsubsection{Decentralization Theorem}

This theorem was put forward by Oates (1972), according to him "For a public good the consumption of which is defined over geographical subsets of the total population, and for which the costs at providing each level of output of the good in each jurisdiction are the same for the central or for the respective local government - it will always be more efficient (or at least as efficient) for local governments to provide the pareto - efficient levels of output for their respective jurisdictions than for the central government to provide any specified and uniform level of output across all jurisdictions". Hence Oates (1972) argues that provision of public goods in the face of market failure are more efficiently provided by subnational governments than by Federal Governments, for the theoretical reason that average demand of a small group (say at subnational level) is convergent as compared to the diverse demand at the federal level. This demand seem peculiar at subnational level than Federal level and providing public goods that meets the average demand of households in a given population group will improve economic welfare. This implies that devolution of expenditure powers to subnational governments increases macro-economic performance, welfare and efficiency in the provision of public goods when the output approximates the average demands of households in that geographical jurisdiction that internalizes its provision and should include precisely the set of individuals that consumer it.

Thus, the theory of fiscal decentralization rests on the foundation that efficient allocation of public resource to match preferences for service is facilitated by factors such as; access to local knowledge, alignment of resources to services, local financial autonomy in planning and service delivery, scope for achieving cost- effectiveness in service delivery and performance accountability in service provision. The theory posits that welfare would be maximized if each local government provides the pareto-efficient output for its constituency.

\subsubsection{Musgrave's Theory of Fiscal Federalism}

Musgrave classical treatise of 1959 laid a strong foundation for fiscal decentralization, where he classified the economic functions of government into three; stabilization, distribution and allocation functions. The stabilization function relates to aggregate demand, fiscal policy and the maintenance of price stability. The distribution function is based on tax and transfers, such that a given level of economic efficiency is consistent with ethical notions of the appropriate distribution of house hold incomes. The allocation functions are concerned with the production and provision of public goods and services which the market system failed to produce efficiently.

These three fold functions of the government have their implications for fiscal decentralization. The stabilization function of the government is effectively and efficiently done at the national level, as stabilization policy is self-defeating if undertaken by subnational government, since fiscal policy that is locally financed is likely to benefit other areas/regions other than the area/region financing the activity. This suggests that for efficiency, stabilization policies are best handled at the federal level. The distributive function as while should be effectively 
left to the central government. According to Musgrave and Musgrave (1989)" whereas the Federal government had to be granted basic taxing powers by the constitution the states did not need this provision. Taxing power of the states is vested in their sovereign rights as constituent members of the federation and retained by them under the residual power doctrine. The constitution, however, imposes certain restrictions on the taxing power of the states, partly through specific provisions and partly again through judicial application of other clauses of the constitution to tax matters". This explains clearly why distributive function in best left to the central government except for those taxes which the subnational government is deemed to handle more efficiently because of their localized nature. While the allocation function, depending upon the economies of scale in production and diversity of taste in demand are theoretically, effectively and efficiently undertaken by subnational government.

\subsection{Empirical Studies}

Fornasari, Webb and Zou (2000); Martinez-Vazques and MacNab (2006); King and Ma (2001); Neyapti (2004) in their studies found that fiscal decentralization stimulate macroeconomic stability and economic growth. Feltenstein and Iwata (2005); and Thornton (2007) found a negative and insignificant relationship between fiscal decentralization and macroeconomic stability.

In their cross-sectional study, King and Ma (2001) investigated the impact of revenue decentralization on macroeconomic stability for 49 countries from 1973 to 1994. Their results show a negative relationship between macroeconomic instability, measured as average inflation rate, and revenue decentralization for developing countries and insignificant for the rest of the countries in the study. Also, using a panel data set for developed and developing countries, Neyapti (2004) investigated the relationship between revenue decentralization and inflation. His findings show that revenue decentralization has a negative effect on inflation when accompanied by a greater degree of central bank independence and local accountability. His study strongly suggests that decentralization leads to lower inflation provided monetary discipline exists.

Shah (2006) used cross- sectional data to study 40 countries for the period 1995 to 2000 . The outcome shows that fiscal decentralization has a negative but insignificant impact on price inflation. He concluded that the impact of fiscal decentralization on management of inflation and macroeconomic imbalances is positive but insignificant. Thornton (2007) conducted a panel regression study of 19 Organization for Economic Co-operation and Development (OECD) countries over the period 1980 to 2000 and found that when the measures of revenue decentralization are limited to the revenue of sub-national governments, its impact on inflation is not statistically significant.

Treisman (2000) investigated the impact of fiscal decentralization on average inflation rates in a panel of 87 countries. His findings show clear divergence in the relationship between fiscal decentralization and inflation among developed and developing countries. Among OECD countries fiscal decentralization is linked with significantly lower average inflation rates in the 1970s and 1980s. Among non-OECD countries, more politically and fiscal centralized economies suffered from higher average inflation rates. Empirical analysis suggests that decentralization helps preserve central bank independence in OECD countries, while in non OECD countries it increases pressures on the government to overspend and get central bank to monetize the deficit.

Feltenstein and Iwata (2002) investigated the impact of fiscal decentralization on economic growth in China, using a vector autoregressive (VAR) model. Their findings reveal a strong correlation between decentralization and macroeconomic performance in China. Their findings further reveal that whereas fiscal decentralization has positive effects on growth of real output in post-war China, it results in adverse effect when related to the rate of inflation. In conclusion, the study argues that fiscal decentralization seems good for economic growth but bad for price stability.

Using panel data set for 52 developing and developed countries between the period 1972-1997, Martinez-Vezquez and MacNab (2006) investigated the direct and indirect relationship between fiscal decentralization, economic growth and macroeconomic stability. Their findings showed that decentralization positively influences price stability in developed countries, though this impact is much less clear in developing and transitional countries. Samuelson (1954) and Oates $(1972,1993)$ have argued that decentralization of government expenditure increases economic efficiency since local governments have better information about local preferences of citizens. As a corollary to these findings, De Mello (2000) argues that decentralization is expected to boost accountability and transparency in service delivery. In addition, if tax payers perceive that local accountability exists, they will better cooperate with local governments in terms of their obligations. These arguments suggest that decentralization may lead to lower budget deficits and lower inflation through increased efficiency in public service delivery.

Ekpo and Ndebbio (1996) also examined the fiscal operations in the Nigerian economy using a historical cum 
political economy approach. They argue that states were more dependent on the federal government before the economic crisis of 1979 and 1980. However, during the economic stabilization and adjustment period, the country witnessed greater fiscal decentralization. Aigbokhan (1999) and Barro (1990) used endogenous growth model to investigate the pattern of fiscal decentralization on economic growth in the country. The study found a high ratio of concentration of both expenditure and revenues, which appeared skewed in favor of decentralization. On the effect of decentralization on economic growth, the study found that rather than promote economic growth, the prevailing pattern of fiscal decentralization acts as a constraint to economic growth.

In yet another study in Nigeria, Taiwo (1999) provided a theoretical basis for fiscal federalism and analyzed the various fiscal problems the country was facing. The study argues that the central government should assume distribution and stabilization functions and the provision of national public goods. States and local governments should take up the responsibility of providing local public goods. The study, among other things recommended that the various tiers of government should jointly participate in central revenue collection and sharing. The study hinges the success of fiscal federalism on liberal democracy, technical and administrative capacity building, local autonomy and revenue mobilization to support government activities.

\section{Methodology}

\subsection{Data Sources}

This study employed secondary data collected from the following sources; Central bank of Nigeria's statistical bulletin (various issues including 1999, 2006 and 2012 editions); National bureau of statistics' statistical fact sheets; CBN's annual reports (various editions); www.economywatch.com; www.knoema.com; and indexmundi.com. the data series sourced therefrom and used in this study include: misery index (midex), fiscal decentralization-revenue (fidr), fiscal decentralization -expenditure (fide), and fiscal dependence (fisdep).

\subsection{Model Specification}

In this study, the researchers measure macroeconomic performance and economic stability using the misery index as proxy. The misery index certainly approximates the Nigeria economy very closely as it is the combination of inflation and unemployment which have simultaneously continued to be on the raise in the Nigeria economy. Thus the misery index can be written as follows:

$$
\text { Midex }=\text { Unem }+ \text { Inf }
$$

Where

Midex = Misery index;

Unem = Unemployment;

Inf $=$ Inflation rate.

While it is agreed that unemployment and inflation reduce aggregate demand for goods and services, thus impeding growth in output, it is the focus of this study that revenue and expenditure decentralization is the prime determinant of macroeconomic performance and stability in Nigeria, hence the following equation

$$
\text { Midex }=f(\text { Fidr }+ \text { Fide })
$$

Where

Fidr $=$ Revenue decentralization;

Fide $=$ Expenditure decentralization

However, fiscal dependence (fisdep) was introduced into the model as an explanatory variable. This was supported by theory and empirical studies as can be seen from the above section. Fisdep shows whether sub-national governments are dependent or not on the central government for revenue and expenditure. Therefore, to determine the effects of fiscal (revenue and expenditure) decentralization on macroeconomic performance, the following model is presented below:

$$
\text { Midex }=f \text { (Fidr, Fide, Fisdep) }
$$

Thus: Midex $=\propto_{o}+\propto_{1}$ Fidr $+\propto_{2}$ Fide $+\propto_{3}$ fisdep $+\mu, \propto_{1}, \propto_{2}, \propto_{3} \leq 0 ; \propto_{3} \geq 0$.

The a priori expectation of revenue and expenditure decentralization is quite confusing. Martinez-Vezquez and Macnab (2006) argued that fiscal decentralization has an indirect effect on macroeconomic performance. Expenditure decentralization at the sub-national level is more efficient, because sub-national governments are closer to the citizens and therefore, are in better to position understand their pressing needs (Oates, 1999). While De Mello (2000) opined that decentralization promotes local accountability and transparency and if locals 
perceived that a high level of accountability exists in services delivery, they will cooperate with sub-national governments. Hence we expect revenue and expenditure decentralization and investment to have inverse relationship with macroeconomic stability, while fiscal dependency is expected to be positive if sub-national governments are independent and of course, negative if they are dependent.

Where

Midex $=$ Misery index (the sum of inflation and unemployment rates);

Fidr $=$ Revenue decentralization (the ratio of sub-national government revenue to total federal revenue);

Fide $=$ Expenditure decentralization (the ratio of sub-national government expenditure to federal government expenditure);

Fisdep = fiscal dependency (the ratio of sub-national governments internally generated revenue to the total collected revenue).

In testing for long-run relationship between the variables of interest, this study adopts the Johansen co-integration test. The test involved co-integration with deterministic trend in the vector auto regression (VAR). The test was conducted at 5 percent significance levels. This study proposes that changes in fiscal decentralization and other relevant controlled variables in this study affect changes in macroeconomic performance and stability in the long-run. However, the variables to be tested using the Johansen cointegration tests need to be stationary, and to tests the variables of interest for this condition the researchers adopted the Augmented Dickey-Fuller (ADF) unit root test. The $\mathrm{ADF}$ is based on the hypothesis that $\lambda_{0}=0$ against the alternative hypothesis that $\lambda_{0}<1$ as shown below:

$$
\Delta X_{t}=b_{o}+b_{1 t}+\lambda_{o} X_{t-1}+\sum Y_{t} \Delta X_{t-1} \mu_{t}
$$

Where:

$\Delta=$ is the difference operator;

$\mathrm{b}_{\mathrm{o}}=$ is the intercept;

$\mathrm{t}=\mathrm{a}$ time trend;

$\mu_{\mathrm{t}}=$ is the error term.

The Johansen (1995) cointegration text is based on the vector auto-regression of order $\mathrm{p}$ given by

$$
\propto_{\mathrm{t}}=\mu_{\mathrm{t}}+\mathrm{b}_{1} \propto_{\mathrm{t}-1}+\ldots+\mathrm{b}_{\mathrm{p}} \propto_{\mathrm{t}-\mathrm{p}}
$$

Where:

$\alpha_{t}=$ is an $n x 1$ vector of variables that are integrated of order one and $\mu_{t}$ is an $n x 1$ vector of innovation.

\section{Results and Discussion of Findings}

\subsection{Stationarity Test}

The table below shows the stationarity of the time series data using ADF. The ADF test statistic revealed that all-time series data in this study are stationary at first difference at 5percent level of significance.

Table 1. Augmented dickey-fuller test statistic

\begin{tabular}{ccccccc}
\hline & t- statistic & Critical value 1\% & Critical value 5\% & Critical value 10\% & Prob. & Decision \\
\hline MIDEX & -5.829558 & -3.679322 & -2.967767 & -2.622989 & 0.0000 & $\mathrm{I}(1)$ \\
FIDR & -6.421818 & -3.670170 & -2.963972 & -2.621007 & 0.0000 & $\mathrm{I}(1)$ \\
FIDE & -5.692988 & -3.670170 & -2.963972 & -2.621007 & 0.0001 & $\mathrm{I}(1)$ \\
FISDEP & -5.165606 & -3.670170 & -2.963972 & -2.621007 & 0.0002 & $\mathrm{I}(1)$ \\
\hline
\end{tabular}

\subsection{Cointegration Test}

Using the Johansen cointegration test we seek to determine whether there exist long-run equilibrium relationships among the variables of interest. The trace test revealed that there is one cointegrating equation at 5 percent level of significance. This was supported by the maximum eigenvalue test with one cointegrating equation at 5 percent level of significance. See table below. 
Table 2. Johansen Cointegration test

\begin{tabular}{|c|c|c|c|c|}
\hline \multicolumn{5}{|c|}{ Sample (adjusted): 19832012} \\
\hline \multicolumn{5}{|c|}{ Included observations: 30 after adjustments } \\
\hline \multicolumn{5}{|c|}{ Trend assumption: Linear deterministic trend } \\
\hline \multicolumn{5}{|c|}{ Series: MIDEX FIDR FIDE FISDEP } \\
\hline \multicolumn{5}{|c|}{ Lags interval (in first differences): 1 to 1} \\
\hline \multicolumn{5}{|c|}{ Unrestricted Cointegration Rank Test (Trace) } \\
\hline Hypothesized & & Trace & 0.05 & \\
\hline No. of $\mathrm{CE}(\mathrm{s})$ & Eigenvalue & Statistic & Critical Value & Prob.** \\
\hline None * & 0.636123 & 58.44343 & 47.85613 & 0.0037 \\
\hline At most 1 & 0.471114 & 28.11527 & 29.79707 & 0.0772 \\
\hline At most 2 & 0.257779 & 9.005794 & 15.49471 & 0.3648 \\
\hline At most 3 & 0.002083 & 0.062554 & 3.841466 & 0.8025 \\
\hline \multicolumn{5}{|c|}{ Trace test indicates 1 cointegrating eqn(s) at the 0.05 level } \\
\hline \multicolumn{5}{|c|}{ Unrestricted Cointegration Rank Test (Maximum Eigenvalue) } \\
\hline Hypothesized & & Max-Eigen & 0.05 & \\
\hline No. of CE(s) & Eigenvalue & Statistic & Critical Value & Prob.** \\
\hline None * & 0.636123 & 30.32817 & 27.58434 & 0.0217 \\
\hline At most 1 & 0.471114 & 19.10947 & 21.13162 & 0.0937 \\
\hline At most 2 & 0.257779 & 8.943240 & 14.26460 & 0.2909 \\
\hline At most 3 & 0.002083 & 0.062554 & 3.841466 & 0.8025 \\
\hline
\end{tabular}

From the table above the trace statistic of 58.44343 is greater the 5 per cent critical values of 47.85613 hence, we are not accepting the null hypothesis and concluded that there is at least one cointegrating relationship and therefore, a long run equilibrium relationship exist among the variables.

The maximum eigenvalues test also supported this claim of long-run equilibrium relationships among the variables. The maximum eigenvalue statistics of 30.32817 , is greater than the critical value at 5 percent level of significance of 27.58434 respectively, thus we do not accept the null hypothesis of no cointegration among the variables.

\subsection{Error Correction Mechanism}

The parsimonious error correction framework below revealed that all explanatory variables under study are not significant at 5 percent critical level at current value with coefficient and t-statistics in bracket as follows; $-8.999418(-0.332044)$ and $18.40994(0.306703)$ being for fiscal decentralization-revenue (Fisdr) and fiscal dependence (fisdep) respectively. However, fiscal decentralization-expenditure lag 1 and fiscal decentralization revenue lag1 (fidr(-1)) and lag 2 (fidr(-2)) are significant at 1 percent, 5 percent and 10 percent critical levels respectively with positive sign, running contrary to the expected signs for this study, indicating that these variables (fide(-1), fidr(-1) and fidr(-2)) are positively related to Nigeria's macroeconomic stability thus, stimulating inflation and unemployment (stagflation) in Nigeria. While fiscal dependence lag 3 and lag 4 are significant at 5 percent critical levels with mixed signs.

The error correction term (ECM) was rightly signed, although it was not statistically significant. The value of Durbin Watson statistic of 1.43 reveals the absence of auto-correlation, while the $\mathrm{R}^{2}$ value of 0.72 revealed that the model is of a good fit and the explanatory variables accounting for 72 percent variation in macroeconomic stability in Nigeria, while the overall model was significant at 5 percent critical level.

Table 3. Error Correction model

\begin{tabular}{|c|c|c|c|c|}
\hline \multicolumn{5}{|c|}{ Dependent Variable: D(MIDEX) } \\
\hline \multicolumn{5}{|c|}{ Method: Least Squares } \\
\hline \multicolumn{5}{|c|}{ Sample (adjusted): 19862012} \\
\hline \multicolumn{5}{|c|}{ Included observations: 27 after adjustments } \\
\hline Variable & Coefficient & Std. Error & t-Statistic & Prob. \\
\hline $\mathrm{C}$ & 5.108562 & 2.690668 & 1.898622 & 0.0770 \\
\hline $\mathrm{D}(\mathrm{FIDE}(-1))$ & 60.35333 & 18.61885 & 3.241517 & 0.0055 \\
\hline $\mathrm{D}(\mathrm{FIDE}(-2))$ & -32.30800 & 24.14356 & -1.338162 & 0.2008 \\
\hline
\end{tabular}




\begin{tabular}{lllll}
\hline D(FIDE(-3)) & -29.90610 & 20.12956 & -1.485681 & 0.1581 \\
D(FIDR) & -8.999418 & 27.10308 & -0.332044 & 0.7445 \\
D(FIDR(-1)) & 58.88852 & 27.47692 & 2.143200 & 0.0489 \\
D(FIDR(-2)) & 47.75158 & 26.37523 & 1.810470 & 0.0903 \\
D(FISDEP) & 18.40994 & 60.02530 & 0.306703 & 0.7633 \\
D(FISDEP(-2)) & -66.86862 & 40.28797 & -1.659766 & 0.1177 \\
D(FISDEP(-3)) & 87.72260 & 33.81845 & 2.593927 & 0.0203 \\
D(FISDEP(-4)) & -80.33325 & 36.49877 & -2.200985 & 0.0438 \\
ECM(-1) & -0.157966 & 0.127845 & -1.235603 & 0.2356 \\
\hline R-squared & 0.717966 & Mean dependent var & 5.053333 \\
Adjusted R-squared & 0.511141 & S.D. dependent var & 17.73822 \\
S.E. of regression & 12.40228 & Akaike info criterion & 8.174741 \\
Sum squared resid & 2307.250 & Schwarz criterion & 8.750668 \\
Log likelihood & -98.35900 & Hannan-Quinn criter. & 8.345994 \\
F-statistic & 3.471372 & Durbin-Watson stat & 1.432442 \\
Prob(F-statistic) & 0.013734 & & \\
\hline
\end{tabular}

\subsection{Stability Test}

Stability test is appropriate in time series data, especially when one is uncertain when changes might occur. The null hypothesis is that the coefficient vector is the same in every period. The stability test in figure 1 and 2 below revealed that neither the cumulative sum of Recursive Residuals (CUSUM) nor cumulative sum of square of Recursive Residuals (CUSUMQ) plots crossed the 5 percent critical lines, therefore, we conclude that the estimated parameters of the study are stable and useful for policy decision and analysis. Thus, the regression equation is stable over time.

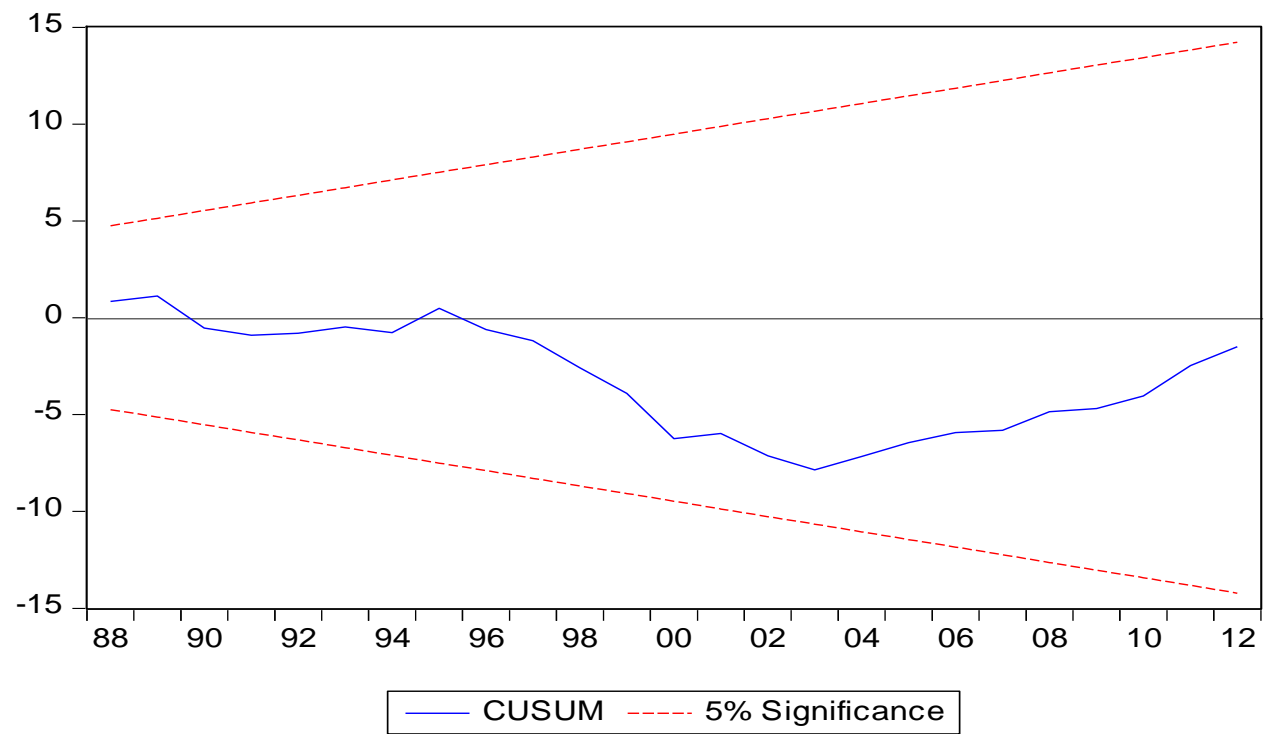

Figure 1. Plot of cumulative sum of recursive residuals 


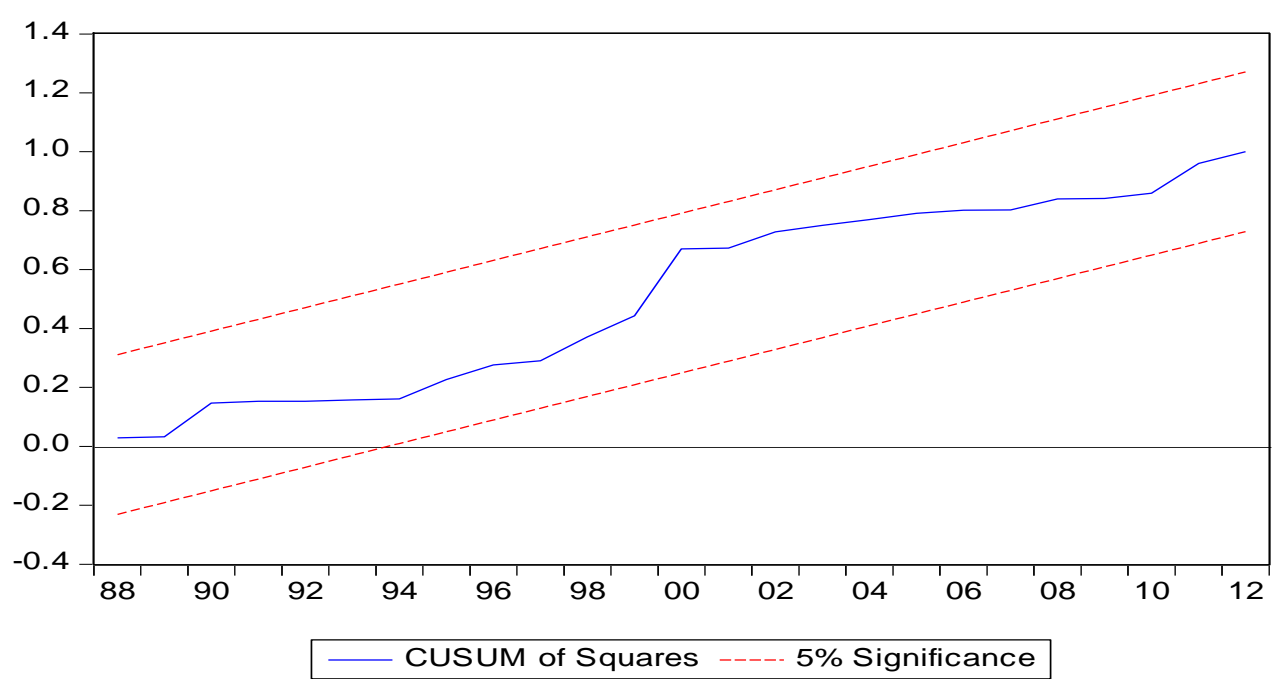

Figure 2. Cumulative sum of square of recursive residuals

\section{Conclusion/ Policy Implication}

The question of whether fiscal federalism challenges could be responsible for poor macroeconomic performance and economic stability in Nigeria has been extensively investigated in this study. The use of Error Correction Model (ECM) estimator with lagged decentralization variables to a set of dynamic time series data models in investigating the research problem has proved quite intuitive, robust, and immensely suitable. This study threw more light on the relationship between fiscal decentralization and macroeconomic performance and stability in Nigeria.

The results of this study highlighted clearly the impact of fiscal decentralization on macroeconomic performance in Nigeria which is found to be mixed, and the policy options available to the Nigerian government. Although decentralization variables at current values conformed to a priori expectation, they are not statistically significant, while the lags though with mixed signs are statistically significant, thus, strongly suggesting that fiscal decentralization supports macroeconomic performance and economic stability in Nigeria in the long run.

Fiscal dependence registered positive a priori sign and statistically significant at 5 percent critical level (i.e. lag 3) indicating that most states and local governments depend almost entirely on the federal allocation and as such have lost initiatives to grow internally generated revenue (IGR). Decentralization and financial autonomy are essential features of fiscal federalism. Subnational governments need to be given access to adequate resources with the sense of accountability to effectively do the job with which they are entrusted. To achieve the relevant policy objectives that relate to ensuring a stable fiscal federalism, questions on true federalism, and how to organize intergovernmental fiscal systems should be pragmatically addressed in order to ensure Nigeria's macroeconomic stability.

\section{References}

Aigbokhan, B. E. (1999). Fiscal Federalism and Economic Growth in Nigeria (pp. 333-352). Proceedings of the Annual Conference of the Nigerian Economic Society.

Barro, R. (1990). Government Spending in a Simple Model of Endogenous Growth. Journal of Political Economy, 98, 103-125. http://dx.doi.org/10.1086/261726

De Mello. (2000). Can Fiscal Decentralization Strengthen Social Capital. IMF Working Paper no. WP/00/129.

Ekpo, A. H., \& Ndebbio, J. E. (1996). Fiscal operations in a depressed economy: Nigeria, 1960-1990. AERC research paper 44, Nairobi: African Economic Research Consortium.

Feltenstein, A., \& Iwata, S. (2002). Fiscal Decentralization and Deficits: International Evidence. Retrieved from http://www.neyapti.bilkent.edu

Feltenstein, A., \& Iwata, S. (2005). Decentralization and macroeconomic performance in China: regional autonomy has its costs. Journal of Development Economics, 8(2), 153-174.

Fornasari, F., Webb, S. B., \& Zou, H. (2000). The Macroeconomic Impact of decentralized Spending and Deficits: International Evidence. Annals of Economics and Finance, 1(2), 403-433. 
King, D., \& Ma, Y. (2001). Fiscal Decentralization, Central Bank Independence and Inflation. Economic Letter, 72, 95-98. http://dx.doi.org/10.1016/S0165-1765(01)00405-0

Martinez-Vazquesz, J., \& Macnab, R. M. (2006). Fiscal Decentralization, Macro Stability and Growth. Hacienda Publica Espannola/Revista de Economica Publica, 179(4), 25-49.

Musgrave, R. A., \& Musgrave, P. B. (1989). Public Finance in Theory and Practice. McGraw-Hill Book company, New York.

Neyapti, B. (2004). Fiscal Decentralization, Central Bank Independence and Inflation: A Panel Investigation. Economic Letters, 82(2), 227-230. http://dx.doi.org/10.1016/j.econlet.2003.09.005

Nnamocha, P. N. (2002). Public Finance for a Developing Economy: the Nigerian Application. BON Publishers, Owerri.

Oates, W. E. (1972). Fiscal Decentralization. New York: Harcourt Brace Jovanovich.

Shah, A. (2005). Fiscal Decentralization and Macroeconomic Management. International Tax and Public Finance, 13, 437-462. http://dx.doi.org/10.1007/s10797-006-8948-1

Taiwo, I. O. (1999). Fiscal Federalism: A Theoretical Framework (pp. 3-23). A Paper Presented at the Annual Conference of the Nigerian Economic Society.

Thornton, J. (2007). Fiscal decentralization and economic growth reconsidered. Journal of Urban Economics, 61(1), 64-70. http://dx.doi.org/10.1016/j.jue.2006.06.001

Thornton, J. (1999). Further Evidence on Revenue Decentralization and Inflation. Economic Letters, 95(I), 140145.

Treisman, D. (2002). Decentralization and Inflation, Commitment, Collective action or Continuity. American Political Science Review, 94(4), 837-857. http://dx.doi.org/10.2307/2586211

\section{Copyrights}

Copyright for this article is retained by the author(s), with first publication rights granted to the journal.

This is an open-access article distributed under the terms and conditions of the Creative Commons Attribution license (http://creativecommons.org/licenses/by/3.0/). 